\title{
A natureza e a geografia: o olhar de João José Bigarela
}

João José Bigarela*

\section{Introdução}

Gostaria de falar um pouco de quando eu me formei em 1943 na faculdade de filosofia na universidade, quando não havia pesquisa. Porém, naquela época, em janeirode 1944 fui nomeado, pelo interventor Manoel Ribas, como assistente voluntário do museu paranaense e, a partir daí, quando eles faziam excursão, principalmente ao litoral, foi onde eu compareci, vendo como os pesquisadores da Universidade de São Paulo, do Rio de Janeiro e de outros lugares trabalhavam. Naturalmente fiquei atraído, embora estivessem pesquisando sobre ecologia, ou sobre botânica, me deram a chance de me aproximar da linha da geologia, e como proceder nos trabalhos de campo.

$\mathrm{Eu}$, na época da II Guerra Mundial, estava fazendo o curso superior, passei a adorar a topografia, que é uma topografia diferente daquelas da faculdade e engenharia. Ali a gente conseguia fazer levantamentos expeditos, que são fabulosos, em que se usa uma bússola e um passômetro e se estabelece, mede o passo médio no plano, na subida e na descida. Tem que introduzir o fator de correção, e com isso a gente faz uma série de encaminhamentos, principalmente quando fazia pesquisa de matéria-prima para a indústria do cimento e também procurando matéria-prima para cerâmica.

Com um mapa expedido, surgiram as primeiras fotografias aéreas, fixava uma fotografia numa prancheta e, sobre isso, colocava-se um plástico duro que se chamava "astralão" e, em cima disso, a gente desenhava o itinerário onde estavam os rios e os

Professor da Universidade Federal do Paraná.

Geosul, Florianópolis, v. 29, ESPECIAL, p 151-153, jul./dez. 2014 
BIGARELA, J.J. Natureza e a geografia: o olhar de João José Bigarela.

caminhos, andando a pé sempre, nada de fazer, como muitas vezes, faz-se de carro. A distância e na velocidade do carro se diz: "Olha lá aquilo" e "boom" já viu a coisa errada. Então tem que fazer com cuidado, principalmente o trabalho de campo.

Foi com bons trabalhos de campo que pude conseguir o mapeamento dos Sambaquis. Eu tinha dois remadores em canoa, peguei o eixo da canoa, coloquei na bússola e medi o tempo em que eles faziam um determinado itinerário. Para determinar a distância, a largura do rio eu usava um mapeamento deste, visando para um lado e depois para o outro do rio.

O primeiro mapa foi publicado em 1958, e quando a gente vê o mapa, depois compara com as fotografias aéreas, a diferença é um alongado; mas a morfologia da Bahia e a localização dos Tambaquis estão iguais. Bom, estas são as vantagens. Queria dizer também que o meu professor principal de Geologia e Geomorfologia foi um marco, não vou dizer que foi um alienígena, mas, um cara que dizia que "o geólogo/Geógrafo tem que aprender a ler a mão da guerra". Tudo que a gente quer, a gente consegue por meio desse método, isso não é mistério. Com esse método, a gente pode avançar muito rápido em uma região.

Todo esse contexto para afirmar que a gente vai usar continuamente o trabalho de campo. Em 1951, eu tive uma bolsa de pesquisa nos Estados Unidos. Percorri de Leste a Oeste e fui de Norte a Sul, tendo o procedimento da ida ao campo com orientandos em mestrado e doutorando, vendo como eles operavam. Na Califórnia, por exemplo, o instituto oceanográfico foi também um lugar muito bom para obter essas informações. Então, é uma somatória de coisas que a gente pode tirar do campo, pode anotar e pode usar para fazer um trabalho bom.

Mas nos Estado Unidos se tivesse inquisição, e eu lá, adepto à teoria de Wegner da separação dos continentes, seria queimado em uma fogueira, mas depois de certo tempo eles descobriam nas pesquisas oceânicas a gravidade disso e mudaram de opinião. Então fomos passar de um continente para o outro, onde existiriam 
BIGARELA, J.J. Natureza e a geografia: o olhar de João José Bigarela.

pontos através do oceano, onde poderíamos pular de ilha em ilha ou navegar de carona, para provar a deriva continental.

Por exemplo, há cerca de 2,3 bilhões de anos há rochas tanto na África, quanto no Maranhão e aqui na região do Uruguai e em Santa Catarina, no sul de Barra Velha. Lá também tem um terraço marinho de 8 metros de altura. Eu não tenho dados da América do Norte. É como se tivesse um motorista, dirigindo as Placas Tectônicas, ele é muito barbeiro, ele está indo, indo, e de repente se bate com outra placa, se amassa tanto na Ásia quanto da Índia, e na Índia levanta o Himalaia. Aqui na América do Sul, ele se choca contra a placa de Nascar que levanta a Cordilheira do Andes. Então tudo consequência da Deriva Continental dessa parte tectônica.

Vocês já viram ou já fizeram uma sopa, de grão de arroz, e outras coisas na panela, fiquem olhando o que acontece com o grão de arroz. Acho que ninguém observou. Basicamente o grão sobe do centro para cima e desce pelas paredes para voltar ao fundo. Bem, foi esse efeito que também afetou a deriva continental.

Houve um pesquisador da Hungria que veio aqui no Paraná e que no caso eu o conduzi para ele coletar material. Ele perfurava a rocha e coletava um cilindro. Ele tinha um comportamento curioso, ele quase não falava, então estava caminhando com ele para levá-lo em afloramentos, quando chegamos ao alto eu disse para ele: "was fur ein schoner Tag" ele não disse nada, na volta ele falou "wirklich ist". Entenderam? Eu disse: "que dia bonito" e ele não disse nada do que eu disse para ele, e na volta ele disse para mim "realmente é".

Recebido em Novembro de 2014

Aceito em Dezembro de 2014 